\title{
ISAAC OF NINEVEH AND THE WRITINGS OF “ MACARIUS OF EGYPT.
}

ASSEMAN I noted ${ }^{1}$ that quotations from a Macarius occurred in the works of Isaac of Nineveh. J. B. Chabot likewise observed ${ }^{2}$ the general fact that citations did occur in Isaac from a saint of the name of Macarius. A more precise examination, however, is desirable for these passages, in view of the importance of Isaac of Nineveh as a witness to Macarius's writings.

Isaac's importance lies in his comparatively early date. He flourished towards the end of the seventh century." ' $\mathrm{He}$ is the author of several ascetic sermons preserved in the original Syriac, and in the Greek and Latin versions (Migne $P . G$. lxxxvi $\mathrm{r}, 8 \mathrm{r} \mathrm{I}-886$ ), also in an unreliable Arabic version, and in an Ethiopic version derived from the same.' ${ }^{4}$

Isaac's quotations from Macarius, about to be examined, may be found in two books: ( 1 ) the edition of Isaac of Nineveh in Greek by Theotokes, 1770 , Leipzig, ${ }^{5}$ and (2) the edition of Mar Isaacus Ninivita in Syriac entitled De Perfectione Religiosa by Paulus Bedjan, Pars, I gog.

A. First may be mentioned passages where Macarius is referred to in connexion with the other saints of the Egyptian desert, Ammoun, Pachomius, Arsenius, and Antonius. Incidents are related, which occur also in the Apophthegmata and in various accounts of holy men known as Paradisı Patrum. For instance:-

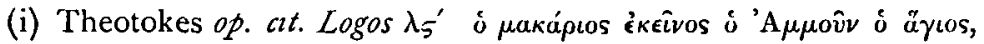

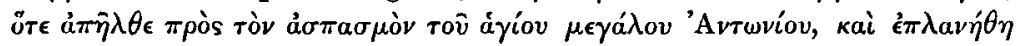

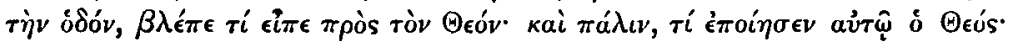

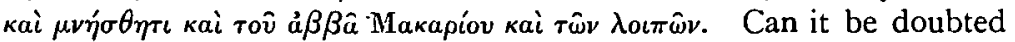
that Isaac is here drawing from the Book of Paradise (Syriac Text, edited with an English translation by E. A. IV. Budge 1904, vol. ii $\$ 44 \mathrm{I}$ p. 74I $\rangle$ where Abbâ Ammon is said to have lost hıs way going to Abbâ Antony, and after praying ' $I$ beseech Thee, $O$ Lord God, not to destroy that which thou hast created' found himself miraculously transferred to the cave of Abbâ Antony? Thereupon in immediate

I Bibl. Or. i, Romae $1719,44^{\mathrm{S}}$.

2 De S. Isaaci Ninvitae vita, scmptıs et doctrnua, Lovanıi, I892, †1.

s See Chabot's edition of Jésusdenah's Livre de la chasteté (Mélanges, \&c., of the French school at Rome, 16, 1896).

- Bardenhewer Patrologie, second edition, Engl. trans., p. 397.

5 The only copy of this book in England is in the British Museum. 


\section{THE JOURNAL OF THEOLOGICAL STUDIES}

proximity occur wonderful examples of St Macaruus's humility, e.g. $\S 43^{8}$ the alternate praising and vilifying the dead who remain equally impassive and imperturbable at both, and $\$ \$ 443,444$ his victory over the Devil armed with a scythe.

(ii) Bedjan op. cit. p. 3 Iol. ro; cf. eund. p. $5^{6}{ }_{3} 1.8$; Theotokes op. ctt. $E p$. A p: 528 . After relating the reluctance of Arsenius to admit even so important a visitor as the Bishop of Alexandria, Theophilus, Isaac

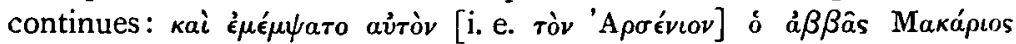

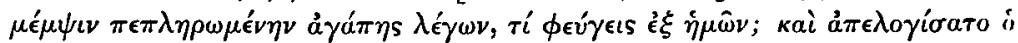

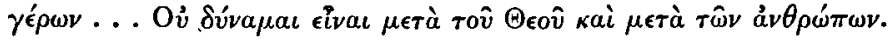

Unquestionably Isaac is drawing from the seventh of the $A p o p h$ -

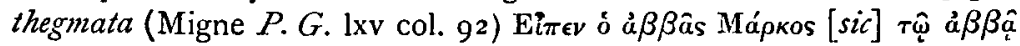

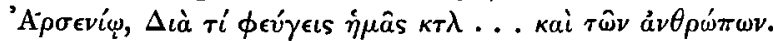

(iii) Theotokes $o p$. cit. $E p . \delta$ p. 350 , Macarius aged ninety goes from Scetis to Alexandria to buy fresh bread for a sick brother. The source is incontrovertibly The Book of Paradise (ed. Budge I904, vol. is $\S \S 395,396$ pp. 721,722 ).

B. Secondly, turning to quotations in Isaac of Nineveh from Mācarius's written works, we may begin by quoting (1) Assemanı's note ${ }^{1}$ on Sermo 38 of the Arabic version of Macarius : '[Isaacus Ninivita] adducit testimonium ... ex Epistola Macarii, cuius initium : Abbas Macarıus'scribit cunctis filiis suis carissimis'. Theotokes has this passage, to which Assemani referred, in $\operatorname{Logos} \mu \theta^{\prime}:-$

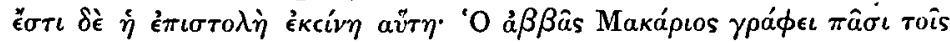

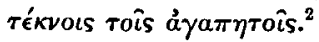

Likewise it is found in Bedjan ${ }^{3}$ in the original Syriac:-

'Also from one of the letters of the blessed Macarius thou canst learn if thou wilt. And the letter is this: Father Macarius wrote to all his beloved children'.' This beginning of a letter is none other than that of the letter preserved in Latin and printed in Migne $P$. $G$. t. xxxiv col. 405. In the Latin these introductory words have dropped out. In the Syriac version of the Letter, however, they are preserved. ${ }^{5}$

(ii) Isaac quotes a parallel which Macarıs draws between the

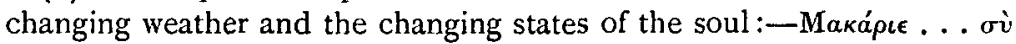

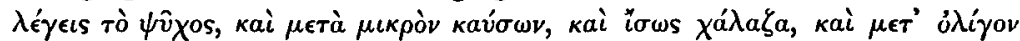
$\epsilon \dot{v} \delta i^{6}{ }^{6}{ }_{\kappa} \lambda$. The original occurs in the Twelfth Syriac Letter ${ }^{7}$ : 'For

1 Bibl. Or. i, Romae, 1719, p. 453.

2 See p. 3 or line 4 of $\log o s \mu \theta^{\prime}$.

3 See p. $5^{\circ 0}$ line 16 of Bedjan's Mar Isaacus Nınivita De Perfectone Relıgiosa, Paris, 1909.

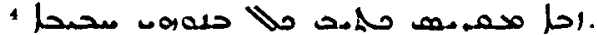

5 See the Syriac MSS of Macarius in the British Museum, Letter i intt.

6 Theotokes Logos $\mu \theta^{\prime}$, p. $2 y 6$.

i See the Syriac MSS already referred to. 
there is cold and after a time heat, and perhaps hail, and a little after calm etc.'

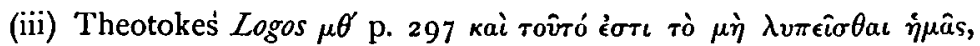

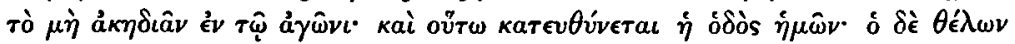

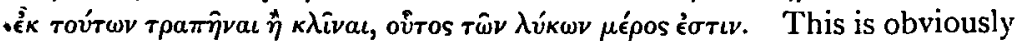
a quotation from a Father. Although Isaac does not mention the Father's name, there is no difficulty in identifying it as Macarius's when we read in the Syriac 'In oppression let us not grieve, and in time of rest that comes from grace let us not take pride...; thus we shall prepare our way, for he who turns aside from this is the portion of wolves'.'

To sum up, therefore, the evidence, both positive and negative, furnished by Isaac of Nineveh : Isaac, in the latter part of the seventh century regarded the fourth-century saint of the Scetic Desert, Macarius, as the author of Letters, not of one Letter alone as Gennadius of Marseilles declared.' While, however, attributing to Macarius the letters still preserved in Syriac, and one in Latin, Isaac knew nothing of the corpus of Homilies as the work of Macarius.

\section{G. L. Marriott.}

\section{GENNADIUS OF MARSEILLES ON MACARIUS OF EGYPT.}

In his De Viris Illustribus ${ }^{3}$ Gennadius of Marseilles gives the following account of Macarius: "Macarius monachus ille Aegyptius ... unam tantum ad minores professionis suae scripsit epistolam, in qua docet, illum perfecte posse Deo servire, qui conditionem creationis suae cognoscens ad omnes semetipsum inclinaverit labores, et luctando atque Dei adversum omne quod in hac vita suave est auxilium implorando, ad naturalem perveniens puritatem, continentiam velut naturae debitum munus obtinuerit.'

Gennadius here speaks of Macarius as the author of a single letter, which he briefly describes as characterized by Pelagian or semi-Pelagian expressions.

1 Macarius, Letter 12

2 Gennadius's error, if so it be, is probably due to a careless reading of the Greek

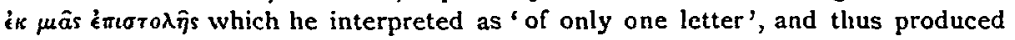
'unam tantum epistolam'.

3 C.ıp 10. 